\title{
The Relationship between India and Indonesia
}

\author{
An Evolving Security Partnership?
}

\begin{abstract}
This article examines the evolution of relations between India and Indonesia. It argues that there are grounds to believe that this relationship may develop into a broadbased security partnership over time. Whether this occurs sooner rather than later will depend on the extent to which both countries see an imperative to turn their numerous complementary interests into practical deeds.
\end{abstract}

KEYWORDS: India, Indonesia, security relationship, maritime security, Malacca Strait

India Is SEEking A DiRect political and security role in Southeast Asia as part of its emergence as a regional power. Indonesia, by virtue of its size, leading role in the region, and geographical position, is likely to become an essential element in India’s regional strategy. For Indonesia, India also represents a potentially attractive partner in its desire to play a significant role in the developing regional order in Asia. This article argues that Indo-Indonesian relations have the potential to eventually evolve into a broad-based security partnership. At present, however, this is an exceedingly gradual process in which both countries have failed to turn their complementary interests into practical deeds.

This article begins by reviewing Indian-Indonesian relations during the Cold War, examining their shared strategic circumstances and their history of rivalry and coexistence. In the second section, it examines post-Cold War developments in Indian strategic perceptions, focusing primarily on India's ambitions to become the predominant maritime security provider in the Indian Ocean. Third, it discusses Indonesian security perceptions in the

David Brewster is a Visiting Fellow with the Strategic and Defense Studies Center, Australian National University. He is currently writing a book on India as an Asia-Pacific great power. The author wishes to thank Ron Huisken, Robert Ayson, and anonymous reviewers for their helpful comments. Email: <dhbrewster@bigpond.com>.

Asian Survey, Vol. 5I, Number 2, pp. 22I-244. ISSN ooo4-4687, electronic ISSN I533-838X. (C) 20II by the Regents of the University of California. All rights reserved. Please direct all requests for permission to photocopy or reproduce article content through the University of California Press's Rights and Permissions website, http://www.ucpressjournals.com/reprintInfo.asp. DOI: AS.20II.5I.2.22I. 
post-Suharto era, including attempts to improve and rebalance Indonesia's relationships with extra-regional powers. Finally, this article analyzes the current dimensions of the Indo-Indonesian strategic relationship, including India's ambitions to gain a maritime security role in the Malacca Strait. It concludes by discussing the overall significance of such a role for India in Southeast Asia.

\section{RIVALRY AND COEXISTENCE DURING THE COLD WAR}

India and Indonesia shared similar strategic perspectives during much of the Cold War, despite periodic friction between them. Both claimed non-aligned status as a way of leveraging their influence between the competing Western and communist blocs. From the I960s, both shared significant concerns about Chinese expansionism and subversion in the region. ${ }^{1}$ Both also claimed a leading role in their respective regions and, with only limited success, sought to minimize the influence of external powers in their respective neighborhoods. Even though both India and Indonesia were opposed to what they viewed as the "neo-imperialism" of the former colonial powers, Western countries (including the U.S.) continued to play important security roles in South and Southeast Asia.

Upon gaining independence in the late 1940 , both India and Indonesia found themselves in similar strategic circumstances. Among the earliest and largest states to gain independence after World War II, both were sprawling multiethnic and multilingual nations struggling to maintain internal cohesion, deal with post-colonial legacies, and claim their desired place in the international order. A close political relationship developed between the two from the late I940s. The newly independent India supported the Indonesian nationalist struggle against the Dutch and subsequently Indonesia's role as a leading post-colonial state. For their part, Indonesian leaders drew inspiration from India's non-aligned posture and its resistance to attempts by the U.S. to draw the newly decolonized states into its anti-Soviet camp. India and Indonesia were also founders of the Non-Aligned Movement (along with Yugoslavia and Egypt) in I96I.

India and Indonesia also saw themselves as the legitimate successor states for peoples who had been arbitrarily divided by the European colonizers. In

I. Among other things, India had suffered a humiliating defeat in a brief war with China in 1962 over disputed territory in the Himalayas. Chinese-supported communists were also blamed for an attempted coup against Indonesian President Sukarno in 1965. 
fact, both spent much of their early years as independent states coming to terms with colonial era divisions: for India, it involved the partition of the subcontinent between it and Muslim-majority Pakistan, and for Indonesia, the division of ethnically Malay, archipelagic islands in Southeast Asia lying between it and Malaysia. India and Indonesia gave each other considerable diplomatic support in absorbing neighboring colonial territories including India's takeover of French Pondicherry in 1954 and Portuguese Goa in I96I, and Indonesia's absorption of Dutch New Guinea in 1963 and Portuguese East Timor in 1975 . Both fought also against ethnic and religious separatism within their respective borders in the attempt to build cohesive and secular states.

However, India and Indonesia were less supportive of each other's broader regional ambitions. In the early I960s, when Indonesia sought to achieve regional hegemony in Southeast Asia by scuttling the creation of an independent Malaya, India gave Malaya significant support in various international forums as well as advocating a continuing security role for Great Britain in the region. Indonesia countered by supporting Pakistan in its 1965 conflict with India, including supplying Pakistan with submarines, missile boats, and MiG fighters (along with Indonesian support crews). ${ }^{2}$ Indonesian President Sukarno even briefly considered seizing the Andaman and Nicobar Islands from India as a way of showing support for Pakistan. In fact, the Indonesian threat to the Andaman Islands was a key reason why the Indian Navy remained in the Bay of Bengal during the 1965 war and failed to take offensive action against Pakistan. ${ }^{3}$ This was a lesson in the strategic importance of Indonesia to India.

The rivalry between India and Indonesia during the early I960s was aggravated by Indonesia's increasing tilt toward communist China, including the perceived formation of a China-Indonesia-Pakistan axis hostile to India. Indonesian President Sukarno's growing radicalism led him to seek Chinese support against the "neo-imperialist" West and its Third World "lackeys," which, for him, included India. When Sukarno stage-managed attacks by

2. This was disclosed by the former commander-in-chief of the Pakistani Air Force, Asghar Khan. For details, see M. Asghar Khan, The First Round Indo-Pakistan War 1965 (Sahibabad: Vikas Publishing, 1979), pp. 42-47. It appears that Indonesian personnel and equipment arrived in Pakistan too late to see action against India and were withdrawn after President Suharto came to power.

3. This was stated by the Indian Chief of Naval Staff Vice Admiral Bhaskar S. Soman. See Rangit Rai, "Why the Indian Navy Did 'Sweet Fanny Adams' in the 1965 War," Naval Review 98:4 (November 20I0), pp. 379-84. 
mobs on the Indian Embassy in Jakarta in 1962 and again in 1965 , India responded with forbearance, downplaying suggestions that Indonesia presented a significant threat to India. ${ }^{4}$ Sukarno's overthrow in the aftermath of an attempted coup in September 1965 subsequently eased tensions between the two countries. Chinese political influence in Indonesia was swept away, and Jakarta moved quickly to repair damaged relations with India. Indonesia, in fact, effectively ceased to pursue hegemony over maritime Southeast Asia and instead backed the creation of the Association of Southeast Asian Nations (ASEAN). Indonesia also withdrew its military support for Pakistan and backed India's claims over Kashmir. Indonesia and India began sharing the view that China constituted the most significant threat to the region. ${ }^{5}$

India has, in fact, long recognized the key role of Indonesia in Southeast Asia. During the second half of the I96os, India viewed Indonesia and Vietnam as the preeminent regional powers in archipelagic and mainland Southeast Asia, seeing them as cornerstones of any strategy aimed at preventing the expansion of Chinese influence in the region. ${ }^{6}$ India proposed the establishment of an arrangement anchored by India, Indonesia, and Japan to promote regional economic development and to counter increased Chinese influence. For its part, Indonesia was cautious about any arrangement that might be perceived as constituting an anti-China coalition. Despite its shared perceptions about a potential Chinese threat, Jakarta did not wish to provoke China into a conflict that could potentially go beyond Indochina. Indonesia also rejected suggestions that India join ASEAN when it was being established. The Indonesians were wary of bringing India into an already unstable region and also mindful of the potential Indian impact on the balance of power in Southeast Asia and Indonesia's status within ASEAN.

Through the late I960s and I970s, India and Indonesia worked together to limit the influence of "extra-regional" powers in Southeast Asia and the Indian Ocean, especially the U.S. They co-sponsored the Indian Ocean "Zone of Peace" (IOZOP) proposal that would have limited any outside naval presence in the Indian Ocean. (In the long run, this would have left India as the major naval power in the Indian Ocean.) However, while

4. Saroj Pathak, India and Southeast Asia: A Study of Indian Perspective and Policy since I962 (New Delhi: Atma Ram, 1990), pp. I09-IO.

5. Joint communiqué of Indian Foreign Minister M. C. Chagla and Indonesian Foreign Minister Adam Malik, as reported in News from Indonesia, no. 545, January 2I, 1967.

6. Mohammed Ayoob, India and Southeast Asia: Indian Perceptions and Policies (London: Routledge, I990), p. 36. 
Indonesia firmly opposed the presence of all outside naval powers there in the I96os, its thinking later evolved toward accepting what it called a "reasonable balanced presence" of outside powers. ${ }^{7}$ By the late I970s, in light of increasing concerns over the Soviet naval presence, the Indonesians concluded that a limited U.S. presence in the Indian Ocean and Southeast Asia was not necessarily undesirable, and Indonesia stepped down its support for the IOZOP and other proposals to exclude the U.S. from the region. ${ }^{8}$ As Indonesian Foreign Minister Ali Alatas later put it, "We can't keep the four powers [the U.S., Japan, China, and India] out of the region. But there must be equilibrium between them and Southeast Asia."

Although Indonesia had concerns over India's relationship with the Soviet Union, it nevertheless sought to bring India into a closer relationship with ASEAN, proposing that it be given associate status. However, Indonesia's initiatives were torpedoed in 1980 when India recognized the Vietnameseinstalled Cambodian government following Vietnam's invasion of that country-a move that caused outrage among ASEAN states such as Singapore and Thailand. Although Indonesia felt bound to support its more hawkish ASEAN partners in their criticism of India, it was not greatly concerned about India's stance or its connection with Vietnam. The Indonesian military took a relatively relaxed view of communist Vietnam, viewing it as a buffer against spreading Chinese influence.

However, through the I970s, the Indonesian military did become concerned about India's role in assisting the growth of Soviet naval power in the Indian Ocean. Indonesia had extracted a promise from Indian Foreign Minister Swaran Singh in 1974 that New Delhi would not provide the Soviet Navy with facilities in the Andaman Sea. ${ }^{10}$ However, by the mid-I980s, there was open concern in Indonesian military circles about India's naval expansion program and the possible use of India's Great Nicobar Island by Soviet submarines. An Indonesian military commander reportedly commented that "Soviet submarines were roaming in Indonesian waters around Sabang" and that they came from the Indian base at Nicobar Island. ${ }^{11}$

7. Pathak, India and Southeast Asia, p. 198.

8. The IOZOP proposal is still technically before the U.N., although the committee formed to implement the proposal has met 453 times without result.

9. "Live and Let Live," Far Eastern Economic Review, July II, I99I.

Io. The Statesman (Kolkata), August I2, 1974.

II. Straits Times, Singapore, October I3, 1986. 
Despite concerns over India's relationship with the Soviet Union, the Indonesians did not see India in terms of a threat but more as a potentially destabilizing actor in the region. As a leading Indonesian analyst commented in the early I990s, "Few perceive India as a potential threat, primarily because of its distance. India is still mostly perceived as a South Asian power whose strategic interests are confined to its immediate neighbouring areas." 12 Indonesia did not really consider India a "neighbor" but rather, an extra-regional power like the U.S., Japan, China, and the Soviet Union. India was also seen as a comparable power, holding preeminence in South Asia whereas Indonesia played a leading role in Southeast Asia. ${ }^{13}$

\section{POST-COLD WAR DEVELOPMENTS IN INDIAN STRATEGIC PERCEPTIONS OF SOUTHEAST ASIA AND INDONESIA}

Apart from its diplomatic support for Malaysia in the 1960s, India showed relatively little strategic interest in maritime Southeast Asia during most of the Cold War. Nehruvian strategic doctrine eschewed the development of regional security relationships and, as a result, India saw its interests as largely limited to rhetorical efforts to minimize the intrusion of other major powers into Southeast Asia.

However, the end of the Cold War led to a major reassessment of India's relationships in the region. In 1992, India launched its "Look East" policy to promote economic engagement with the fast-growing economies of Southeast Asia. India’s strategic approach to Southeast Asia currently involves a significant element of balancing against China's growing economic and political influence. Indian Defence Minister Pranab Mukherjee has described this as being "crucial" in maintaining an "equitable" 14 or "stable" power in the region. Indian strategic thinking about archipelagic Southeast Asia is also closely connected with New Delhi's conception of India's security

I2. Dewi Fortuna Anwar, "Changes and Continuity in Indonesia's Regional Outlook," in China, India, Japan, and the Security of Southeast Asia, Chandran Jeshurun, ed. (Singapore: Institute of Southeast Asian Studies, 1993), p. 228.

13. For a detailed analysis, see Franklin B. Weinstein, Indonesian Foreign Policy and Dilemma of Dependence: From Sukarno to Soeharto (Ithaca, N.Y.: Cornell University Press, 1976).

I4. Pranab Mukherjee, address to the Seventh Asian Security Conference, New Delhi, January 29, 2005, <http://www.idsa.in/node/1554>.

15. Pranab Mukherjee, address to the Fifth International Institute of Strategic Affairs Asian Security Summit, Singapore, June 3, 2006, <http://www.iiss.org/programmes/south-asia/ministerialaddresses/pranab-mukherjee/?locale=en $>$. 
role in the Indian Ocean and surrounding maritime zones. Indian strategic thinkers increasingly see the Indian Ocean as India's natural strategic spaceessentially, "India's Ocean." The Indian Navy has come to see itself as destined to become the predominant maritime security provider in a region stretching from the Red Sea to Singapore, and having a significant security role in areas beyond, including the South China Sea. ${ }^{16}$ Indian political leaders currently describe this area as being India's "sphere of influence" ${ }^{17}$ or its "strategic footprint." 18

Since the early I990s, the Indian Navy has taken an active role in extending India's political and strategic reach into Southeast Asia, conducting a coordinated program of naval diplomacy and promoting itself as a benign provider of maritime security. An expansion of Indian naval influence throughout the region has been encouraged by the U.S. The Malacca Strait, the primary point of transit between the Pacific and Indian Oceans and a maritime "choke point," has become a major focus of India's regional maritime strategy. As Foreign Minister Jaswant Singh commented, "An uninterrupted access to the Malacca Strait and the South China Sea, vital for the economies of the ASEAN region and India, needs to be ensured." ${ }^{19}$ According to the Indian Navy's 2004 Maritime Doctrine:

By virtue of geography, we are . . in a position to greatly influence the movement/security of shipping along the [sea lines of communication] in the [Indian Ocean region] provided we have the maritime power to do so. Control of the choke points could be useful as a bargaining chip in the international power game, where the currency of military power remains a stark reality. ${ }^{20}$

Many see India's interest in the Malacca Strait as primarily driven by strategic considerations in dealing with China. Even though a growing proportion of India's trade is with East Asia, the Malacca Strait does not represent

16. For a discussion of the revival of Indian maritime ambitions in the Indian Ocean region, see David Scott, "India's 'Grand Strategy' for the Indian Ocean: Mahanian Visions," Asia-Pacific Review I3:2 (2006), pp. 97-I29.

I7. Chidanand Rajghatta, "Singhing Bush's Praise," Times of India, April 13, 200 .

I8. Manmohan Singh, "PM's Address at the Combined Commanders Conference," October 24, 2004, <http://pmindia.nic.in/speech/content.asp?id=37>.

19. Jaswant Singh, address at the Institute of Strategic and Defence Studies, Singapore, June 2, 2000, as reported in Straits Times, November I5, 2000, p. I7.

20. India, Integrated Headquarters, Ministry of Defence (Navy), Indian Maritime Doctrine, 2004, p. 64 . 
a crucial route for India's energy supplies as it does for China and other East Asian states. Some have even suggested that the Malacca Strait for India is a rough counterpart to the Panama Canal for the U.S., in terms of its ability to maintain regional hegemony. ${ }^{21}$ In any event, the Indian Navy sees an imperative in having the capability to control the strait and its approaches.

India's security engagement with Southeast Asia over the last two decades has given priority to improving multilateral links with ASEAN and developing bilateral ties, particularly with Vietnam and Singapore. ${ }^{22}$ The importance of Indonesia in India's regional strategy has arguably increased. For India, Indonesia is significant in several ways. First, it is by far the largest state in Southeast Asia and is regarded as primus inter pares in ASEAN. A relationship with Indonesia will help India develop its relationship with ASEAN institutions and also its bilateral relationships across the region. Second, Indonesia's historical concern about China makes it a potentially important partner in balancing against China's influence in East Asia, particularly in influencing the development of regional political and economic institutions favorable to India.

Third, Indonesia's geographical location between the Indian and Pacific Oceans makes it key to India's aims to counter China's growing maritime interests in the Indian Ocean, to control the Malacca Strait, and to gain a role as a naval power in the western Pacific. Fourth, Indonesia's cooperative (though independent) security relationship with the U.S. fits well with India's own strategic posture. For India, a political partnership with Indonesia may be useful in increasing its freedom of action in working with the U.S. and its regional allies, while simultaneously promoting the development of a multipolar region. Fifth, India has an important stake in the continued stability and viability of Indonesia — the world's largest Muslim majority nation-as a secular and democratic state. The modern Indian and Indonesian states also share secular traditions, and Indonesia’s relatively tolerant Islamic tradition, infused with mystical Sufi beliefs, has many links with the Islamic Sufi traditions practiced in India. Thus, a secular Indonesia can act as an important bridge for India's dealings with the Islamic world. Indonesia has also generally avoided

2I. James R. Holmes, Andrew C. Winner, and Toshi Yoshihara, Indian Naval Strategy in the 2Ist Century (London: Routledge, 2009), p. I54.

22. David Brewster, "The Strategic Relationship between India and Vietnam: The Search for a Diamond on the South China Sea?" Asian Security 5:I (January 2009), pp. 24-44; and idem, "India's Security Partnership with Singapore," Pacific Review 22:5 (December 2009), pp. 597-618. 
the "Islamic factor" in coloring its relationship with India, including for many years opposing Pakistan's stance on Kashmir in various international forums. ${ }^{23}$ However, an Islamist and non-secular Indonesia could have major ramifications for India's relationships in Asia and the Middle East, as well as India's internal stability. India would likely regard such a development, if it were to occur, in the most serious terms.

\section{INDONESIAN SECURITY PERCEPTIONS IN THE POST-SUHARTO ERA}

As in India, there have also been significant changes in Indonesia's strategic perceptions following the end of the Cold War. Indonesia experienced a succession of economic and political crises in the late I990s beginning with the Asian economic crisis in 1997 (which hit Indonesia particularly hard), then the subsequent fall of the Suharto regime and the transition to democracy, and the separation of East Timor in I999. These were catalysts for Indonesia to readjust its relationships with major powers, including India.

In 2000, President Abdurrahman Wahid, Indonesia's first democratically elected president after the fall of Suharto, unveiled an "Asianist" strategy to reduce Indonesia's economic and political dependence on the West by forging formal or informal alignments with India, China, Japan, and Singapore. ${ }^{24}$ Wahid, while on a visit to New Delhi, proposed a triangular economic alliance between Indonesia, India, and China. Indonesian Defense Minister Mohammad Mahfud later suggested a defense pact among Indonesia, India, China, and Russia. Wahid's proposals, which were founded in mild antiWesternism and vague ideas of "pan-Asian" consciousness, were subject to significant criticism in Indonesia for lacking coherence, and for ignoring bilateral problems between India and China. ${ }^{25}$

While Wahid's proposals were not pursued by subsequent Indonesian administrations, they were indicative of more open thinking about enhancing Indonesia's international status. Since 2004 in particular, Indonesia has adopted a more active foreign policy, showing impatience with the limitations of the "golden cage" of ASEAN and seeking to develop its own bilateral

23. "Indonesia for Security Cooperation with India," The Hindu (Chennai), July 30, I999.

24. Kai He, "Indonesia's Foreign Policy after Suharto: International Pressure, Democratization, and Policy Change," International Relations of the Asia-Pacific 8 (2008), pp. 47-72.

25. Dewi Fortuna Anwar, Indonesia at Large: Collected Writings on ASEAN, Foreign Policy, Security, and Democratisation (Jakarta: Habibie Center, 2005), p. 83. 
relationships with major powers. Indonesia has sought to improve relations with China, announcing a "strategic partnership" in April 2005 involving commitments to collaborate in defense production, and to consult on law enforcement and intelligence. However, there has been little follow through on any of these commitments. ${ }^{26}$ Although ideological differences with China have been reduced in recent years, Sino-Indonesian relations remain strained by their maritime territorial dispute in the South China Sea and continuing resentment of the economically powerful Chinese ethnic minority in Indonesia. The Sino-Indonesian declaration may have amounted to playing a "China card" to accelerate the resumption of U.S.-Indonesian military ties. ${ }^{27}$

Indonesia's relations with the U.S. have also improved in recent years under the Bush and Obama administrations. Although Indonesia continues its rhetoric of calling for an autonomous regional order free from external intervention, Jakarta has indicated that it prefers a continuing U.S. security role in Southeast Asia as a counter to China's rising power. ${ }^{28}$ The new Indonesian administration under President Susilo Bambang Yudhoyono has reinforced previous statements that Indonesia is looking for a new global role that includes taking the lead in the Muslim world. ${ }^{29}$ Recently, there have been influential calls in Jakarta to develop a new regional security management arrangement - a sort of regional concert of powers - that would include Indonesia alongside India, China, Japan, and the U.S. ${ }^{30}$ There has also been increased interest in the Indonesian security community for promotion of democracy in the region, including the establishment of the Bali Democracy Forum in December 2008.

Although Indonesia's strategic posture continues to evolve, there are grounds to believe that it may be increasingly seeing India as an attractive security partner. First, as noted above, the continuing development of a cooperative security relationship between India and the U.S. has brought India's strategic posture much closer to that of Indonesia. Both India and Indonesia are prepared to cooperate politically with the U.S. in a number of

26. Rizal Sukma, "Indonesia Needs a Post-ASEAN Foreign Policy," Jakarta Post, June 30, 2009.

27. Ian Storey, "China and Indonesia: Military-security Ties Fail to Gain Momentum," China Brief 9:4 (February 20, 2009).

28. Ralf Emmers, "Regional Hegemonies and the Exercise of Power in Southeast Asia: A Study of Indonesia and Vietnam," Asian Survey 45:4 (July/August 2005), pp. 645-65, at p. 664.

29. Terry Lacey, "Indonesia Looks to Play on the World Stage," Asia Sentinel, February I, 2010.

30. Jusuf Wanandi, "The ASEAN Charter and Remodelling Regional Architecture," Jakarta Post, November 3, 2008. 
areas, including the creation of "balanced" regional institutions. Second, a relationship with India would fit well with Indonesia's hopes to extend its reach beyond ASEAN toward other major powers and, ultimately, to sit alongside India as a major international player in a multipolar regional order. Third, Indonesia perceives benefit from India's playing an active maritime security role in the region, balancing not only against China but also potentially against U.S. naval predominance. India may well be seen as a useful partner in developing Indonesia's naval capabilities, helping to project its own power regionally.

\section{CURRENT DIMENSIONS OF SECURITY COOPERATION BETWEEN INDIA AND INDONESIA}

Since the mid-I990s, Indonesia has given significant support to India for its ambitions to improve political and security links with the region. Consistent with its longstanding position, Indonesia has played an important role in supporting and encouraging the development of India's institutional relationship with ASEAN. For example, Indonesia had a leading role in supporting India's membership in the ASEAN Regional Forum (ARF) in 1996; in July 1998, it helped to head off significant criticism of India in the ARF over the Pokhran II nuclear tests. After China and others resisted India's inclusion in the ASEAN Plus Three grouping, Indonesia backed creation of the annual ASEAN-India Summit in 2002. ${ }^{31}$ Indonesia was also a strong supporter of India's participation in the East Asian Summit of 2005. ${ }^{32}$ While Indonesia has generally allowed Singapore to take the lead as India's regional advocate, India has acknowledged that Indonesian support has been essential at each step in India's growing engagement with ASEAN.

Since the turn of this century, there have been significant developments in the bilateral relationship between India and Indonesia, and the tempo of visits and meetings between their high-level leaders has increased markedly. Much of the emphasis, particularly from the Indonesian side, has been on the development of an economic relationship between the two. For Indonesia, India represents a potential source of capital and a major market

3r. The ASEAN Plus Three Cooperation grouping brings the ASEAN states together with China, Japan, and South Korea. Formed in 1997, it now has 57 bodies coordinating policy on economic and technical issues.

32. Jusuf Wanandi, Global, Regional, and National: Strategic Issues and Linkages (Jakarta: Center for Strategic and International Studies, 2006), p. 257. 
for Indonesian agricultural products. Nevertheless, trading links have been relatively slow to develop, and actual Indian investment in Indonesia to date has been minimal. A bilateral free-trade agreement has been stalled since 2005 on issues of access to Indian markets for Indonesian palm oil and other key agricultural products. Yet, this evolving economic relationship may have been given fresh impetus following the signing of the India-ASEAN freetrade agreement in 2009. The January 2011 visit of Yudhoyono to India as chief guest for its Republic Day celebrations also indicates a renewed focus on the relationship. Bilateral trade, which topped \$I2 billion in 2010, is targeted to reach $\$ 25$ billion by 2015 . Major Indian investments in Indonesia were also announced with an aggregate value of \$15 billion, including plans by the Indian steel authority to develop a $\$ 3.3$ billion steel plant in Kalimantan.

Over the past decade, there have been important developments in the bilateral security sphere, including agreements on defense cooperation in 200I, joint naval patrols in the Andaman Sea in 2002, and terrorism in 2004. In 2005, Indian Prime Minister Manmohan Singh and Yudhoyono declared a "New Strategic Partnership" that placed significant emphasis on political, defense, and security cooperation, including the creation of an annual strategic dialogue between senior officials. Maritime security, as discussed below, is likely to remain the key focus.

\section{Defense Industry Cooperation}

In January 200I, a defense cooperation agreement was signed during a visit by Indian Prime Minister Atal Bihari Vajpayee to Jakarta. Although primarily dealing with the supply of training and equipment by India and the development of an Indonesian defense industry, the agreement is seen as having broader symbolic value, particularly following its approval by the Indonesian Parliament. Indian assistance in defense technology and training could, at least in theory, be of particular value to Indonesia in light of India's capabilities in Russian-designed equipment and Indonesia's goal of diversifying its defense suppliers. According to an Indonesian Foreign Ministry spokesman, defense industry cooperation with India would "help enhance security in the region" and that would "be a way for Indonesia to help ASEAN nations check the power of China." ${ }^{33}$ 
There has been little real progress in the defense supply relationship. Indonesia has, among other things, unsuccessfully sought to acquire from India radar systems, BrahMos cruise missiles, ${ }^{34}$ and training for its Russianbuilt SU-30 aircraft. ${ }^{35}$ Jakarta is currently evaluating the possible purchase of Indian advanced light helicopters and has indicated interest in Indian participation in a proposed program to build corvette warships. Indian expertise in communications and networking technology has also been sought.

However, the prospect of India's becoming a significant supplier of defense technology and services to Indonesia is restricted by both the small size of Indonesia's defense acquisition budget and India's own limitations. Among these, the supply of radar systems and missiles to Indonesia was vetoed by India's European and Russian partners. India was unwilling to provide operational training for Indonesia's SU-30 aircraft, fearing the risk of disclosure to third parties (i.e., Pakistan) of information on its frontline strike fighters. Others in the region, such as Vietnam, have also experienced problems with Indian political caution, bureaucratic bottlenecks, and export restrictions, especially in the supply of defense technology. As a result, at least in the medium term, it seems likely that cooperation in the field of defense supply will remain limited.

\section{Cooperation in Combating Islamic Extremism}

India has also been in a position to provide assistance to Indonesia in countering domestic threats from Islamic jihadists. Indonesia's vulnerability in this area, and its potential as a source of regional instability, was underlined through the rise of Islamic extremist cells based in Indonesia after 9/II, and the Bali and Marriott bombings of 2002 and 2003, respectively. Then-President Wahid publicly supported India's position on terrorism in January 200I. ${ }^{36}$ The arrest by Pakistani authorities of senior members of Indonesia's Jemaah Islamiyah (Islamic Congregation), while training in Pakistan with the Kashmir separatist group Laskar-e-Taiba (Army of the Pure), led to a memorandum of understanding in July 2004 between Indonesia and India

34. "Indonesia and Malaysia Keen on Buying BrahMos," Frontier India Strategic and Defence, April I3, 2007, <http://frontierindia.net/indianesia-and-malasia-keen-on-buying-brahmos>.

35. Amitav Ranjan, "India Says Not Yet to Indonesian Plea," Indian Express (New Delhi), April 2I, 2004 .

36. T. R. Ramachandran, "Wahid Backs India on Kashmir," The Tribune (Chandigarh), January I2, 200 I. 
on combating international terrorism. In November, Indonesia requested additional Indian assistance in countering terrorism, with an emphasis on maritime security, including a proposal to create what the Indonesians termed an "institutional arrangement." ${ }^{37}$ Shared interests in combating Muslim extremist terrorism were underlined in July 2009 when both countries made a joint plea at the ARF for more effective intelligence sharing in the region. ${ }^{38}$

\section{Maritime Security Cooperation in the Andaman Sea}

India has made a concerted effort to develop a strong maritime security relationship with Indonesia. Even before the end of the Cold War, India began implementing confidence-building measures in maritime security, including hosting joint naval exercises with Indonesia and other regional partners. India and Indonesia commenced bilateral naval exercises off Surabaya in 1989 and in the Andaman Sea, which lies west of the Malay Peninsula and north of Sumatra, in 1991. Several years later, India instituted the biennial naval gathering in the Andaman Islands with the Indonesian Navy and those of other regional powers. India also invited senior Indonesian naval officers to inspect Indian naval facilities in the Andaman and Nicobar Islands to allay Indonesian concerns over their bases.

The separatist insurgency in Indonesia's Aceh Province (located on the western end of Sumatra, around 150 kilometers from India’s Nicobar Islands) was another focal point in developing the Indian-Indonesian security relationship in the early years of this decade. India and Indonesia, as large, ethnically and religiously diverse states, have had a long-running mutual interest in opposing separatism within each other's borders. In fact, since independence, they have provided mutual diplomatic and political support on issues of territorial integrity. The Islamic-inspired insurgency in Aceh gained momentum following the separation of East Timor in 1999 and formed a focus of Prime Minister Vajpayee's visit to Jakarta in January 200I, during which he emphasized India's support for Indonesia's sovereignty and territorial integrity. ${ }^{39}$ For Indonesia, the possible secession of Aceh Province represented an existential

37. "Indonesia Seeks India’s Cooperation to Counter Terrorism," Financial Times, November 29, 2004 .

38. Sandeep Dikshit, "India, Indonesia Call for Better Intelligence-Sharing to Tackle Terror," The Hindu (Chennai), July 24, 2009.

39. Sonia Trikha, "Indonesia Changes Its Stance, Supports India's Bid for UN Security Council Seat," Indian Express, January II, 200I. 
threat, although this has been significantly reduced following the 2005 peace agreement granting the province a significant degree of autonomy. For India, Aceh's significance was not only as a case of separatism or a potential source of jihadist terrorism (as important as those issues are), but rather that Aceh also commands the western entrance to the Malacca Strait. Some fear that an independent and fundamentalist Aceh might obstruct international use of the strait or that China might obtain port facilities in an independent or autonomous province. ${ }^{40}$ At least prior to 2005 , Acehnese insurgents were believed to have been involved in the hijacking of merchant vessels off $\mathrm{Su}$ matra, both as a political statement and a source of funding.

India played only a very limited role in helping settle the Aceh conflict. Indian weapons inspectors participated in the international joint security committee monitoring team in 2003, and the Indian Navy made a prominent contribution to relief efforts in Aceh following the December 2004 tsunami. India did not, however, participate in the international Aceh Monitoring Mission (comprised primarily of EU and ASEAN representatives) established after the 2005 peace agreement. Nevertheless, the Indian Navy has used the Aceh conflict to build bilateral naval cooperation with Indonesia in the Andaman Sea. The Andaman Sea provides regional extremist groups with a key route for communications and travel.

In April 2002, Indonesian President Megawati Sukarnoputri expressed concerns about Aceh rebels finding support within India. ${ }^{41}$ The Indians in turn pressed Indonesia to make a cooperative response, claiming there was evidence of links between Aceh insurgents and Pakistan's Inter-Services Intelligence agency and the use of isolated islands in the Nicobar group for gunrunning to Aceh. ${ }^{42}$ This led to an agreement by which the Indian and Indonesian navies undertook biannual "coordinated" naval patrols throughout the Andaman Sea and at the northern entrance to the Malacca Strait. Since 2002, these patrols have comprised Indian and Indonesian vessels and aircraft, commanded out of India's joint operations command in the Andaman Islands. Although token in practical terms, such joint military operations have significant symbolic value.

40. See Donald K. Emmerson, "Indonesia’s Eleventh Hour in Aceh," PacNet Newsletter, no. 49, December 17, 1998; and Pankaj K. Jha, "India-Indonesia: Emerging Strategic Confluence in the Indian Ocean," Strategic Analysis 32:3 (May 2008), p. 454.

4I. Atul Andeja, "India, Indonesia Anchor New Partnership," The Hindu, April 4, 2002.

42. Other observers have been highly skeptical of any link between the Aceh independence movement Gerakan Aceh Merdeka (GAM) and Pakistan. 
Although security concerns in Aceh Province and related piracy in the Malacca Strait have substantially diminished since the 2005 peace agreement, the region remains a concern for the Indonesian military. In February 2009, Indonesian Army Chief of Staff General Agustadi Sasongko Purnomo proposed creating direct links between the Indonesian military command in Aceh and the Indian military command in Andaman to allow army units operating in the area to work directly together. In March 2009, joint patrols were also intensified to prevent Sri Lankan Tamil Tiger rebels from taking refuge on Indonesian territory.

\section{China's "String of Pearls"}

While India has been able to demonstrate its value as a maritime security partner in the Andaman Sea, it has been less successful in nurturing concerns in Indonesia about the growth of Chinese naval influence in the Indian Ocean. Since the early I990s, Indian officials and commentators have repeatedly raised concerns about a perceived Chinese plan for maritime encirclement of India through the so-called String of Pearls strategy. This has included claims of Chinese involvement in developing naval facilities at points throughout the northern Indian Ocean. Indian analysts assert that China has established naval facilities on both Burma's mainland and its islands in the Andaman Sea. ${ }^{43}$ India also expressed concerns to Indonesia over Chinese involvement in a proposed port facility in the Pulau Weh Islands of Aceh Province, off the tip of Sumatra. According to one Indian observer, although Southeast Asian countries have historically seen the "China threat" as emerging from the east through Indochina and the South China Sea, they should be concerned about the opening of a new "front" via Chinese expansion into the Indian Ocean. ${ }^{44}$ Although some observers have cast doubts about Indian assertions about the "String of Pearls," particularly in relation to Chinese influence in Burma and the Andaman Sea, ${ }^{45}$ such claims continue to be used by India to justify its naval buildup in the Indian Ocean.

43. See, for example, Gurpreet S. Khurana, "China's 'String of Pearls' in the Indian Ocean and Its Security Implications," Strategic Analysis 32:I (January 2008), pp. I-39.

44. Mohan Malik, "Sino-Indian Relations and India's Eastern Strategy," in Sandy Gordon and Stephen Henningham, eds., India Looks East: An Emerging Power and Its Asia-Pacific Neighbours (Canberra: Australian National University, I995), pp. II9-63.

45. See Andrew Selth, "Chinese Military Bases in Burma: The Explosion of a Myth," Regional Outlook Paper (Brisbane, Griffith University), no. Io (2007). 
However, there is little evidence that concerns of a Chinese naval presence in the Indian Ocean are high on Indonesia's agenda. Instead, Indonesia's maritime security concerns about China are focused on the South China Sea, including their long-running dispute over competing territorial claims to the oil-rich waters adjacent to Indonesia's Natuna Islands northwest of Kalimantan (Borneo). ${ }^{46}$ Indonesia also has a maritime territorial dispute with Malaysia in the Ambalat area of the Celebes Sea. It is apparent that while both India and Indonesia are generally concerned about China's power in the region, these concerns have not yet coalesced into a shared perspective on a China threat to Indian Ocean security. ${ }^{47}$ Nevertheless, the "String of Pearls" continues to be a significant issue in Indian strategic thinking and is an important factor in India's thinking about its relationship with Indonesia. India may, for example, encourage Indonesia to play a greater role in bringing political reform to Burma, with the hope that a more open Burmese government would be less susceptible to Chinese influence.

\section{Security in the Malacca Strait}

One issue of continuing importance in the Indo-Indonesian relationship is India's ambition to act as a security provider for the Malacca Strait. The strait, the key maritime transit route between the Indian and Pacific Oceans, is one of the world's busiest waterways, carrying over 62,00o ship movements in 2006. It is the key trade route between East Asia and Europe, carrying an estimated one-third of global trade and the bulk of energy supplies from the Middle East to East Asia (including an estimated $70 \%-80 \%$ of China's energy imports and 90\% of Japan's). ${ }^{48}$ The strait, some 550 nautical miles long whose navigable route narrows to less than one nautical mile, is considered particularly prone to both piracy and potential terrorist attacks. According to official figures, piracy and sea robbery within the Malacca Strait peaked in 2004 with some 2I actual incidents, falling to four actual

46. See, generally, Ian James Storey, "Indonesia’s China Policy in the New Order and Beyond: Problems and Prospects," Contemporary Southeast Asia 22:I (April 2000), pp. I45-74.

47. A senior Indonesian official reportedly voiced concerns in the mid-I99os over China's assistance to Burma in establishing a naval base in the Irrawaddy Delta. For elaboration, see Michael Vatikiotis and Bertil Lintner, "Pariah No More," Far Eastern Economic Review, March 3, 1994, p. 27.

48. Ian Storey, "Securing Southeast Asia's Sea Lanes: A Work in Progress," Asia Policy, no. 6 (July 2008), pp. 95-I27. 
cases in 2010. ${ }^{49}$ Since 200I, politically motivated piracy or terrorism have been of particular concern, including attacks believed to have been planned by al-Qaeda, Jemaah Islamiyah, and other jihadist organizations on merchant and naval vessels in the Malacca Strait and surrounding areas.

Security in the Strait is complicated by legal and political issues surrounding its status. The Malacca Strait, as traditionally defined, is largely within the territorial waters of Indonesia, Malaysia, and Singapore. Under international law, foreign naval vessels have a right of transit only. Foreign naval vessels may escort other transiting vessels while transiting themselves, but, at least according to the littoral states, they may not conduct armed patrols. Indonesia and Malaysia are particularly jealous in safeguarding their sovereignty over the strait, and both are highly sensitive to the presence of any "external" maritime security providers.

There has been significant controversy in recent years over moves by the U.S. and other major users to take a role in providing maritime security in the strait in light of the threats of piracy and terrorist attacks. After the 9/II attacks in 200I, the American and Indian navies provided escorts for high value commercial traffic through the Malacca Strait in support of U.S. operations in Afghanistan. In April 2004, the U.S. announced the Regional Maritime Security Initiative (RMSI), under which it proposed to provide security in the Malacca Strait in partnership with littoral states. The RMSI was strongly opposed by Indonesia and Malaysia, which were weary of a lasting U.S. military presence in the strait. Indonesia and Malaysia also refused to formally participate in the Japanese-sponsored multilateral ReCAAP system, involving the voluntary exchange of information regarding piracy and other security threats in the Malacca Strait.

That July, at the initiative of Indonesia, the three littoral states commenced the so-called MALSINDO (Malaysia Singapore Indonesia) "coordinated" naval patrols. Although seen as a step in addressing international security concerns, the effectiveness of this program is hampered by, among other things, significant limitations in the maritime security capabilities of Indonesia and Malaysia. With continued piracy incidents, the Lloyd's of London insurance association declared the Malacca Strait equivalent to a war-risk zone in June 2005, and shipping companies subsequently began

49. Data taken from ReCAAP [Regional Cooperation Agreement on Combating Piracy and Armed Robbery Against Ships in Asia] Information Sharing Center, ReCAAP ISC Annual Report 2007 (Singapore); and ibid., 2010. 
employing armed private security operators for their vessels..$^{50}$ Indonesia is particularly sensitive to claims that it is the weakest link among littoral states in terms of maritime security and air surveillance capabilities. ${ }^{51}$ Although there has been some success in recent years in reducing incidents of piracy, observers are concerned about Indonesia's acute lack of resources and the likelihood that it will succumb to "patrol fatigue." ${ }_{22}$

Since the mid-I990s, India has placed significant emphasis on achieving naval predominance in the Bay of Bengal and the western approaches to the Malacca Strait. This has included the construction of military facilities in the portion of the Andaman Islands under New Delhi's control, as the base for a new tri-service Far Eastern Strategic Command. The Andaman Islands effectively act as a "cork" at the northwestern end of the Malacca Strait and form a natural base for projecting power. Nevertheless, India has been careful to position itself as a potential benign security provider in the Strait, and to ensure that any naval presence was seen as "non-intrusive, cooperative and benign" by the littoral states..$^{53}$ The Indian Navy's participation in the U.S.led Operation Enduring Freedom in Afghanistan in 200I was publicly supported by Singapore, whereas Malaysia and Indonesia were consulted by India but did not lend their public support to the operation. According to one Indian naval officer, "Our role [in the Malacca Strait] is being perceived as that of a responsible nation, which can create a balance in the region. Also, everyone realizes that India has no ambitions of hegemony." ${ }^{54}$

In the wake of the RMSI controversy in 2004, India publicly distanced itself from the U.S. In February 2006, the U.S. convened a "user-state" conference to discuss security in the Malacca Strait, during which India was vocal in opposing what was claimed to be a unilateralist American approach. In contrast, India insisted that any proposal from the meeting must be subject to the unanimous consent of littoral states. ${ }^{55}$ At the same time, New Delhi has consistently lobbied littoral states for an active security role in the

50. The Malacca Strait was later removed from Lloyd's war risk list, in August 2006.

5I. See, generally, Shafiah Fifi Muhibat, "Competing to Secure the Straits of Malacca and Singapore," Indonesian Quarterly 35:3 (2007), pp. 242-53.

52. Storey, "Securing Southeast Asia’s Sea Lanes," p. I20.

53. Ramtanu Maitra, "India Bids to Rule the Waves," Asia Times, October 19, 2005.

54. Gurpreet S. Khurana, "Safeguarding the Malacca Straits," IDSA Comment, January 5, 2005, <http://www.idsa.in/idsastrategiccomments/SafeguardingtheMalaccaStraits_GUKhurana_050I05>.

55. Idem, "The Malacca Straits 'Conundrum' and India," in Changing Security Dynamics in Southeast Asia, N. S. Sisodia and Sreeradha Datta, eds. (New Delhi: Magnum Books, 2008), p. I34. 
Strait. This included reportedly using the official biennial Milan (Hindi word for "gathering") naval meeting to lobby the littoral states, including Indonesia, for an operational role in the strait. ${ }^{56}$ In June 2006, Indian Defense Minister Pranab Mukherjee reaffirmed India's offers to provide assistance, but only "subject to the desire of the littoral states." ${ }^{7} \mathrm{He}$ also supported the proposal by Indonesia and other littoral states for a compulsory pilotage program through the strait, and backed cooperative proposals relating to safety and environmental protection. In light of political sensitivities about any perceived internationalization of the strait, some observers have argued that an extended definition of the "Malacca Strait" from the Singapore Strait in the south to the Six Degree Channel in the north would include Thailand and India as "littoral" states and allow for the creation of a composite security system of joint patrols.$^{58}$ India has also sought to categorize itself and Thailand as "funnel states" to the Strait of Malacca, thereby justifying a greater security role for themselves there than for other major "user" states.

Indonesia has been ambivalent about an Indian security role in the strait. In July 2005, an Indonesian Foreign Ministry spokesman publicly rebuffed Indian requests for a security role, telling Indian Chief of Naval Staff Admiral Arun Prakesh that responsibility for safety in the Malacca Strait lay with Indonesia, Malaysia, and Singapore only. ${ }^{59}$ This led Prakesh to deny that India had any intention of patrolling the Malacca Strait. In June 2007, Indonesian Defense Minister Juwono Sudarsono deflected renewed requests from the Indian defense minister for a patrol role, saying Jakarta was keen that India, South Korea, China, and Japan "pitch in to provide infrastructure of secure passage of trade through the Strait of Malacca." ${ }^{60}$

Nevertheless, the Indonesian military appears to take a generally benign view of an Indian maritime security role in and around the strait. In March 2009, a meeting of the ARF in Jakarta produced an invitation to Thailand

56. Shiv Aroor, “Centre Approves Navy's Malacca Plan,” Indian Express, January II, 2006.

57. Pranab Mukherjee, address at the Shangri-La Dialogue, Singapore, June 3, 2006, <http:// www.pib.nic.in/newsite/AdvSearch.aspx>.

58. Rajeev Sawhney, "Redefining the Limits of the Straits: A Composite Malacca Straits Security System," Rajaratnam School of International Studies Commentaries, no. 37 (May I8, 2006).

59. Rakesh Sinha, "Jakarta Says No to Indian Patrol in Malacca Straits," Indian Express, July I3, 2005 .

6o. P. S. Suryanarayana, "Indonesia for Defence Tie-up with India," The Hindu (Chennai), June 5, 2007. 
to join with Indonesia, Malaysia, and Singapore in the MALSINDO coordinated patrols. ${ }^{61}$ The Indonesian military also reportedly requested India to take part in maintaining security in the Malacca Strait, on the basis that "all approaches to the strait will be more secure for international shipping." 62

It remains to be seen what level of Indian involvement Malaysia would tolerate. India's relations with Malaysia have been uneasy for some years. Malaysia’s Islamic-oriented foreign policy, its economic and political relationship with China, and political demands by Malaysia's Indian ethnic minority have all led it to be suspicious of India's ambitions in the region. Still, although Kuala Lumpur has previously publicly opposed an Indian role in the strait, it may be softening its stand. For example, in 2005, Malaysian Prime Minister Abdullah Ahmad Badawi reportedly told Indian Prime Minister Singh that Malaysia holds the key to India's ambitions in the Malacca Strait and the South China Sea. Abdullah reportedly said his country was ready for a strategic partnership with India, provided that India's security ties with Thailand are scaled down. ${ }^{63}$ In 2008 , Malaysia consented to an Indian role in the "Eye in the Sky" project to provide air surveillance over the strait, and appears to have at least tacitly consented to an Indian role there. ${ }^{64} \mathrm{Ma}$ laysia's views may have softened as a result of Indian offers to provide training and technical support for Malaysia's MiG-29 aircraft and Scorpène-class submarines. India's strong relationship with Singapore and its developing links with Indonesia may also have prompted Malaysia to improve its relationship with India as well.

The U.S. is supportive of the Indian Navy's security role in the Malacca Strait. In 2006, the commander of the U.S. Pacific Fleet, Admiral Gary Roughead, commented that his country was "not interested" in patrolling the region. According to the Chairman of the U.S. Joint Chiefs of Staff General Peter Pace, the U.S. was "very comfortable with the fact that India

6I. "Thai to Join RI Patrolling Malacca Strait," Jakarta Post, March I6, 2009. This had the effect of extending the definition of the Malacca Strait north toward Indian waters.

62. "Indonesia Asks India to Help Maintain Malacca Strait Security," Xinhua News Agency, March 5, 2009. The Indonesian Foreign Ministry kept its silence on the request.

63. This has included India-Thai joint naval patrols in the Andaman Sea. "Malaysia Warns India against Thailand," Newsinsight, January 3, 2005, <http://www.newsinsight.net/>.

64. P. S. Suryanarayana, "India, Malaysia to Step up Defence Ties," The Hindu (Chennai), January 8, 2008; and "Indian Air Force Chief to Visit Malaysia; Boost in Military Ties," <http:// www.india-defence.com/reports-397ı>, accessed November I8, 20 IO. 
has offered its assistance" in the strait. ${ }^{65}$ Interestingly, it is also possible that China may be prepared to tolerate a limited role for India in the Malacca Strait as an alternative to a U.S. presence. As the Chinese ambassador to India commented in 2005, "Now, geographically, you [India] have access to that area. As far as India is concerned, we don't have any problem. . . But if Americans come and put their battleships there, we might worry about it." ${ }_{66}$

For Indonesia, any invitation to India to assist in security in the Malacca Strait would represent an important departure from Jakarta's position on sovereignty over the vital shipping lane. Nevertheless, the Indonesian Navy may see it as a useful way to build a closer relationship with its Indian counterpart. The Indonesian Navy has extensive responsibilities in policing the country's some I7,000 islands. Although the navy has a relatively large number of vessels, it has very low operational efficiency, and many ships are approaching obsolescence. ${ }^{67}$ To the extent that Indonesia may require external maritime security assistance in the future, India may represent a convenient compromise candidate. Certainly, if Indonesia comes under renewed international pressure to ensure security in the Malacca Strait, it may find it politically more acceptable to work with India than with the U.S., Japan, or certainly China. There may also be scenarios in which India is allowed to participate in ensuring security in the strait as a way of forestalling possible action by the U.S. ${ }^{68}$

Any security role for India in the Malacca Strait would be a significant step for its foreign policy and sense of international prestige. Moreover, such a role would help legitimize India's claims to be a benign security provider to the region as a whole. Cooperation between the Indian and Indonesian navies would provide an opportunity for significant expansion of bilateral military relationships, and would also likely presage increased political cooperation in dealing with other regional security issues. In the near term, it seems likely that India will need to content itself with gaining a Recognized Maritime Picture (RMP) of the Malacca Strait (as well as the Singapore,

65. "Indian Navy Awaits Regional Nod for Patrolling Malacca Straits," <http://www.india-defence.com/reports-2046>, June 7, 2006, accessed November I8, 2010.

66. Khurana, "The Malacca Straits 'Conundrum' and India."

67. In 2004 it was reported that out of II7 vessels only 30 were operational. Ioannis Gatsiounis, "Malacca Strait: Target for Terror," Asia Times, August II, 2004, <http://www.atimes.com/atimes/ Southeast_Asia/FHiIAeo2.html>, accessed November I8, 2010.

68. Rajiv Sikri, Challenge and Strategy: Rethinking India's Foreign Policy (New Delhi: Sage, 2009). 
Lombok, and Sunda Straits) through its relationships with the U.S., Indonesia, and Singapore. ${ }^{69}$

\section{CONCLUSION}

What are the prospects for a broad-based security partnership between India and Indonesia? Although there are some caveats, there are several reasons to believe that the security relationship will continue to develop, although perhaps slowly. Despite periods of rivalry or friction in the past, similarities in their respective strategic perspectives are likely to lead to many commonalities in interest. Both countries have long-held concerns about the growth of China's power; both wish to see the development of a multipolar regional order in which they are recognized internationally as regional powers; and both see a cooperative (but limited) security relationship with the U.S. as a means of increasing their own power and prestige.

Furthermore, India is increasingly likely to see a close relationship with Indonesia as being a key to its increasing ambitions in Southeast Asia. Indonesia's leading role in Southeast Asia, together with its geographic position as gatekeeper between the Indian and Pacific Oceans, makes it an essential partner in India's efforts to project its power into the Asia-Pacific region. For its part, Indonesia has long sought to bring India into a closer relationship with ASEAN, although it has also been careful to maintain a leading role in Southeast Asia for itself. Indonesia is also likely to see India as useful in balancing the growth of China's influence in the region and as a potential partial alternative to relying on the U.S. as an external security provider. This is consistent with the balancing approach followed by many Southeast Asian states. However, unlike the smaller ASEAN states, Indonesia has ambitions to sit alongside the major powers in any future Asian security arrangements.

Nevertheless, one should treat developments in the Indo-Indonesian security relationship with caution. As C. Raja Mohan has commented, "While India has a set of complementary interests with Indonesia, both countries are notorious for their inability to turn words into practical deeds. " ${ }^{70}$ India has, so far, failed to take the initiative in making itself an attractive economic partner to Indonesia. In the security sphere, there is little indication that

69. An RMP is a plot compiled to depict maritime activity.

70. C. Raja Mohan, "Is India an East Asian Power? Explaining New Delhi's Security Politics in the Western Pacific," ISAS Working Paper, no. 8I (August II, 2009), p. I3. 
despite its ambitions, India will become a major supplier of defense technology to Indonesia. India has also not shown itself willing to take risks in providing security assistance. For its part, Indonesia has not demonstrated interest in publicly supporting India in its assertions about China's "String of Pearls" in the Indian Ocean.

Despite these caveats, there are two areas where one might expect further development in the India-Indonesia relationship. One is increased political cooperation in promoting the development of multipolar regional security and economic institutions (e.g., institutions that constrain the influence of China and the U.S., and in which India and perhaps Indonesia have increased leadership roles). The other is in maritime security cooperation including, potentially, the provision of assistance by India in the development of the Indonesian Navy. Although India has pushed hard to gain a role in Malacca Strait security for the last decade, this function seems unlikely for the moment. Nevertheless, such a development would be possible in the event of a significant deterioration in the security environment there. In conclusion, there are certainly grounds to argue that the India-Indonesia relationship is likely to move closer to a broad-based security partnership. However, whether this occurs sooner rather than later depends largely on the extent to which both countries see an imperative to turn their numerous complementary interests into practical deeds. 
Reproduced with permission of the copyright owner. Further reproduction prohibited without permission. 